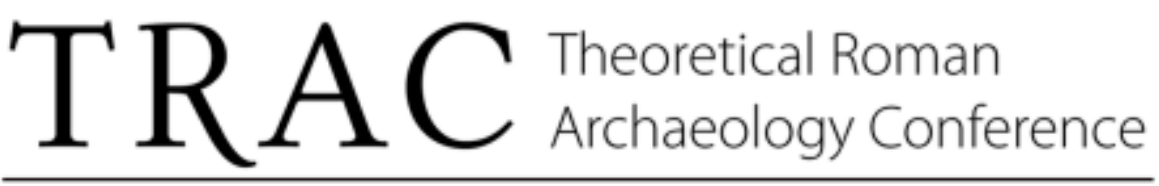 \\ www.trac.org.uk
}

\section{Paper Information:}

Title: Late Roman Frontier Communities in Northern Britain: A Theoretical Context for the 'End' of Hadrian's Wall Author: Rob Collins Pages: $1-11$

DOI: http://doi.org/10.16995/TRAC2005 111

Publication Date: 24 March 2006

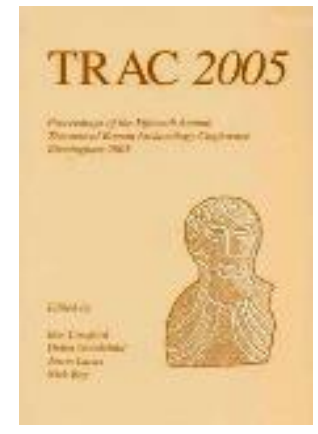

\section{Volume Information:}

Croxford, B., Goodchild, H., Lucas, J., and Ray, N. (eds) 2006. TRAC 2005: Proceedings of the Fifteenth Annual Theoretical Roman Archaeology Conference, Birmingham 2005. Oxford: Oxbow Books.

\section{Copyright and Hardcopy Editions:}

The following paper was originally published in print format by Oxbow Books for TRAC. Hard copy editions of this volume may still be available, and can be purchased direct from Oxbow at http://www.oxbowbooks.com.

TRAC has now made this paper available as Open Access through an agreement with the publisher. Copyright remains with TRAC and the individual author(s), and all use or quotation of this paper and/or its contents must be acknowledged. This paper was released in digital Open Access format in April 2013. 


\title{
Late Roman frontier communities in northern Britain: A theoretical context for the 'end' of Hadrian's Wall
}

\author{
Rob Collins
}

\section{Introduction}

Archaeological and historical research over the past fifty years has demonstrated that the relationship between Roman and Early Medieval Britain is not as clear as was once believed. Hadrian's Wall and other Roman sites in the north have admirably demonstrated the variability of the evidence in respect to this transition (e.g. Wilmott and Wilson 2000). Despite advances in research, however, the transition from imperial frontier to a series of regionally based, dynastic kingdoms, and the processes underlying this transition are still poorly understood. This is a result of the limitations of traditional approaches to the Roman and Early Medieval periods. Northern Britain must be critically examined in its own right as one of many centres of imperial military authority.

The northern frontier of the Empire, monumentally exemplified by Hadrian's Wall, was a distinct landscape that must be studied in its relationship to imperial history but also with sensitivity to regional and local circumstances. The military society and economy of Hadrian's Wall and the northern frontier that established this landscape provide an ideal test area to address an important question: to what extent did the scope of the socio-economic structures operating in the northern frontier change from the fourth to seventh centuries A.D.? This can be broken down into two component questions. One, with the suspension and eventual disappearance of central Roman authority, how did the physical existence of the standing garrison change from the fourth century to the fifth century, and after? Two, how did the economic and social structures of the frontier change, as inferred from the answers to the previous question? Resolving these questions is fundamental to understanding not only the relationship between the frontier zone of late Roman Britain and Early Medieval polities, but transformations in frontier zones across the Western Empire.

While it would be impossible in a paper of this length to fully tackle the questions above, a few small steps can be taken toward an answer. A brief review of academic hypotheses on the 'end' of Hadrian's Wall demonstrates the problems with our current understanding of the evidence. Rather, we must consider the evidence in the greater context of a frontier, by defining what a frontier is and the relevance it has in interpreting evidence from the Wall. The importance of a military garrison in frontier dynamics must also be considered, and the concept of occupational communities provides a theoretical understanding of the limitanei. The use of this sociological theory then enables a framework to be put in place by which archaeologists can interpret the evidence on the ground.

\section{The 'End' of Hadrian's Wall - Past and Present Perspectives}

Academic understanding of the 'end' of Hadrian's Wall is related to varying interpretations of archaeological evidence, resulting in short and long chronology scenarios. Until the 1970s, the 
dominant position was that Hadrian's Wall was abandoned in the late 370s A.D., after Magnus Maximus launched his campaign for the imperial throne on the continent (e.g. Collingwood and Myres 1937). This view, articulated by Craster (1914) and later by Gillam (1949), was based upon existing archaeological evidence, generally a lack of late coins, and the dismissal of the Notitia Dignitatum and the interpretation of it by Bury (1920). However, modern excavation techniques, particularly more careful attention to stratigraphic relationships, have demonstrated this view to be wrong.

From the 1970s until the 1990s, it was argued that Hadrian's Wall was occupied into the early fifth century, as coins from A.D. 397-408 had been found at numerous forts and the Notitia Dignitatum was not to be entirely dismissed in reference to Britain (e.g. Breeze and Dobson 1978). However, withdrawals made by Stilicho in A.D. 401 and the usurper Constantine III in A.D. 407 denuded the Wall of its troops. The general lack of troops to garrison the Wall, even if not abandoned entirely, meant that the frontier could no longer operate effectively; over the course of the early fifth century the troops 'faded away', particularly when the pay coffers dried up (Mann 1979). Related to this was a general agreement on the smaller size of the fourth century garrison of Britain, when compared to the garrison of the second century (James 1984).

The early 1990s saw an alteration of the above perspective, due principally to excavations at Vindolanda (Bidwell 1985), South Shields (Bidwell and Speak 1994), and Birdoswald (Wilmott 1997). These sites arguably demonstrated the occupation at forts into the fifth century beyond A.D. 410, and the new orthodoxy has become that troops on the Wall were not withdrawn before A.D. 410, if at all (Breeze and Dobson 2000: 246). However, official imperial pay ceased by that date, and the impact this had on fort garrisons cannot be stated with any confidence, with the exceptions of the above-mentioned forts. Evidence from other forts suggests activity after A.D. 410 and two opposing stances have developed from this evidence. The first stance argues for an end of the Roman garrison along Hadrian's Wall, the forts of which were later reoccupied in the fifth or sixth century by British and Anglo-Saxon warbands. The second stance argues for continued occupation of forts along the Wall, but displaced from a Roman command/administrative network.

Dark and Dark (1996: 68; reinforcing Dark 1992) have argued that the evidence suggests that the garrison of Hadrian's Wall disbanded rapidly after A.D. 410, coming to an 'abrupt and distinct 'end'. Despite this initial abandonment, however, the Wall was reoccupied at some point later in the fifth or perhaps the early sixth century. Furthermore, it was argued that when the evidence on the Wall is considered in conjunction with other sites in the Roman north (for example York, Catterick, Binchester, Brougham, and Maryport to name just a few), then it is possible to see a pattern suggesting evidence for a sub-Roman, regional potentate loosely based on the territory formerly commanded by the dux Britanniarum. The re-defence along the line of the Wall and the defence of the road between York and the Wall is suggestive of at least regional cooperation between leaders if not a regional potentate. However, this pattern may also be indicative of bias among archaeologists in selecting sites to excavate. Another problem with this interpretation is the assumption of contemporaneous occupation of all the sites. Unfortunately, current dating techniques do not provide the necessary resolution to support this.

Casey (1993), Jones (1996), and Wilmott (2000) have individually argued that the evidence suggests a continuity of military occupation into the fifth century, at least in some form. The garrison along Hadrian's Wall was left in place in A.D. 410, but cut off from pay and state supply mechanisms, the local garrisons would have formed relationships of mutual dependence 
with the surrounding population, exchanging food for protection. Such a localized supply system, it is argued, would have kept the forces along the Wall from uniting under one command because the local elites that emerged along the Wall were probably in direct competition with each other.

These hypotheses on the 'end' of Hadrian's Wall raise two major problems. First, late and sub-Roman activity along the Wall is understood in reference to the collapse of Roman imperial authority in Britain rather than considered in the context of a late frontier. Second, any continuity in the form of military occupation required the logistical needs of the garrison to be met. Such needs are recognized and indicated, but the provision of necessary materials is not explored in any depth. Therefore, the late Roman military economy and its reliance on state subsidy and/or authority on the one hand and local supply on the other must be examined in detail. Given the limitations of evidence for the fifth and sixth centuries, the late Roman period becomes that much more important, as it can establish a 'trajectory' for transformation in the fifth, and perhaps sixth centuries.

What follows is a discussion of the greater context within which we must place the archaeological material that provides a theoretical framework by which we can understand the social and economic transformations that occurred between the fourth and seventh centuries. By the fourth century, northern Britain had been established as a frontier of the Roman Empire for two centuries, and it is this notion of the frontier that must underpin our understanding of the 'end' of Hadrian's Wall. Therefore, the concept of a frontier should be reviewed.

\section{Roman Frontiers - A Conceptual Understanding}

By definition, a frontier is located on the periphery of an entity, outside of its core. This basic relationship, however, has been discussed most frequently in relation to the imperialism of the nineteenth century under which frontiers were established. Until the 1960s and 1970s, frontiers were often considered as 'natural' or 'scientific' boundaries, most often occurring in a linear form due to geographical features such as rivers and mountains, or along lines of ethnic or linguistic difference (Whittaker 1994: 1-9, 60-62). These clean, unambiguous frontiers, however, have been demonstrated to be fallacies conceptualized through a colonialist perspective of core-periphery relationships (Febvre 1922; Lapradelle 1928; Lightfoot and Martinez 1995). In other words, frontiers cannot be conflated with clearly defined boundaries.

Instead, frontiers must be considered as complex and dynamic zones in their own right, related to but separate from political boundaries (Kopytoff 1993; Lightfoot and Martinez 1995; Paynter 1985; Pohl et al. 2001; Turner 1893). Frontiers should be understood as transitional zones. Whittaker (1994: 85; building upon Lattimore's 1940 research on Inner-Asian frontiers of China) argued that Roman frontiers

'....represented a compromise between the range of conquest and the economy of rule. Inevitably this compromise was not a clear geographic dividing line but a broad transitional region - an inner and an outer frontier ... where it was never obvious in the first instance whether the food supply or local production could sustain an army without its becoming an intolerable economic or logistical burden.'

This definition identifies two key features of the frontier. First, it is a transitional zone that connects the core with the 'outside' - socially and economically. Second, the establishment of 
a standing military force reduces the potential for surplus extraction from the frontier directly benefiting the core, and may even require surplus exported from the core to subsidize the frontier.

In addition to this definition, Whittaker argued for a broader identification of a frontier zone beyond a military network or political boundary. Central to his argument was the recognition of the contradiction inherent in the ideology of the Roman Empire (Whittaker 1994: 11, 37, 44, 72). The world belonged to Rome, and the eternal city had the right to rule the entire world. The formal recognition of boundaries of absolute political and military control was impossible because it would deny Rome's right to global domination. However, the difference between a border line and a border zone must not be forgotten. Recognition of a border zone acknowledged the practical limits of direct control in conjunction with the political and economic reality of the day.

Archaeological evidence indicates that most frontiers incorporated administrative and/or logistical (supply) lines, often seen through the distribution of Roman military installations. Linear military works, like Hadrian's Wall in Britain and the clausurae in Africa, were simply a means to control and supervise the movement of people and goods (Breeze and Dobson 2000: 40; Trousset 1980: 935). The full implication of this argument is that administrative lines were not exclusive of people outside the Empire. Rather, a frontier created an area of stability that changed and developed the economic and social dynamics that originally contributed to the formation of the frontier (Whittaker 1994: 97). This stability was due to political, economic, and cultural assimilation of the border peoples so that in the end, it was unclear in the frontier zones exactly who was 'Roman' and who was 'barbarian' (Goetz 2001: 74). As frontiers were organized to supervise and facilitate the transition between the 'outside' and 'inside', those guarding such zones were subject to unique circumstances and pressures.

\section{The Limitanei - An Ancient Occupational Community}

As frontiers have been argued to be transitional zones of contact between the Roman state and various 'barbarian' groups, it is useful to focus on a relatively universal social group that could be found in every frontier - the limitanei. A number of factors make the limitanei an appropriate social group to consider. First, limitanei were stationed in every frontier of the later Roman Empire, and this makes them useful for comparisons between different frontiers. As professional soldiers, they were integrated into the politico-military framework of the Empire, economically, socially, and ideologically. At the same time, the long-term stability of Roman frontiers, the tendency to recruit locally, and the preponderance for tax in kind in the later period socially and economically integrated the limitanei into the frontier sector of their posting. Through the limitanei, then, a frontier can be related to the imperial system while it is also understood in its more localized context.

Recent research regarding the Roman army has focused on more social aspects (e.g. Alston 1995; Goldsworthy and Haynes 1999; Isaac 1990; Pegler 2000; Pollard 1996), dismantling unwarranted comparisons between modern armies and Roman armies and illuminating the relationship between soldiers and their local communities beyond that of a paid fighter (James 2001: 79). The relationships between garrisons and the non-military populations cannot be expected to be exactly the same throughout the Empire, but Haynes' (1999a: 9) advocacy of the sociological and anthropological concept of 'community' has many merits. This is most clearly seen in the sociological concept of an occupational community. 
An occupational community is defined as 'people who are members of the same occupation or who work together have some sort of common life together and are, to some extent, separate from the rest of society' (Salaman 1974: 19 n.4). Occupational communities represent the relationship between a person's work and their life outside of work, in which the nature and conditions of the occupation permeates social relationships, interests, and values. The key defining components are threefold:

'[M]embers of occupational communities see themselves in terms of their occupational role: their self-image is centred on their occupational role in such a way that they see themselves as ... people with specific qualities, interests and abilities.

$[\mathrm{M}]$ embers of occupational communities share a reference group composed of members of the occupational community.

$[\mathrm{M}] \mathrm{embers}$ of occupational communities associate with, and make friends of, other members of their occupation in preference to having friends who are outsiders, and they carry work activities and interests into their non-work lives.'

(Salaman 1974: 21)

In terms of self-image, a member of an occupational community does not see himself solely in this role, as a person's identity is composed of multiple roles determined through various social relationships (Goffman 1969). However, the member places a higher emphasis on his occupational identity (including the qualities and abilities needed for that occupation) that dominates much of his life outside of work. Such membership involves the internalization of a value system that becomes relevant not only to the sphere of work, but also to aspects of life outside of work (Salaman 1974: 24). It is this feature that strengthens the relationships with work colleagues, as they also share the same value system and have similar attitudes. Thus, coworkers become the primary reference group. The reference group is particularly important, as its members can exercise powerful social sanctions that strongly influence the behaviour of the member. Once an occupational community is identified, membership in such a community can be determined by three factors: physical and/or emotional involvement in work tasks; having a defined status, whether high or low; and the inclusiveness of the work or organizational situation (Gerstl 1961; Salaman 1974: 27).

Involvement in work is always to some extent a result of external factors, but certain situations generate a greater sense of involvement. These include potential danger, a sense of responsibility, and a high level of expertise or training. The status of the job relative to other occupations, particularly if it is high status when compared to other local jobs, will generate increased involvement just as marginal status relative to other occupations will also increase involvement (Salaman 1974: 28). Once membership in an occupation is attained, or in some cases granted, certain features of the job will affect non-work activities and interests, which in turn restrict opportunities to establish and maintain relationships with work colleagues and people outside the occupation. These features are identified as types of inclusivity, and there are three primary types: pervasiveness; organizational embrace; and restrictive factors (Salaman 1974: 33-36). Pervasiveness, the number of activities in or outside the organization for which the organization sets norms, varies between occupations (cf. Etzioni 1961). For example, a modern western army set norms and rules that apply to many aspects of its member's life, both in work and outside of it; 'The military profession is more than an occupation: it is a complete style of life' (Janowitz 1960: 175). When a person is subject to a high degree of organizational pervasiveness, often through a value system established by their 
occupation, then non-work life will converge with work life through various activities, interests, and relationships (Salaman 1974: 34).

Organizational embrace, the second type of inclusivity, identifies the extent to which an organization will attempt to control the activities of its members (Etzioni 1961). Control can be accomplished through regulation of sleeping, eating, and recreation activities by supplying the facilities or materials needed for such activity (Salaman 1974: 34). Embrace is most successfully achieved when the only supply of facilities and materials for non-work activities is through the organization. Occurrence of high levels of organizational embrace strongly influences and restricts a member's non-work life and opportunities to establish and maintain relationships with people outside the organization.

The final type of inclusivity is the restrictive factors that affect non-work lives. Restrictive factors differ from embrace in that embrace is a deliberate policy of an organization, while restrictive factors are the result of the way that the work is organized and of certain exigencies of the job itself (Salaman 1974: 35). Examples of restrictive factors include the need to travel and the time of day at which the work is carried out; both of these examples limit the social interaction with people outside the occupation.

Of the three types of inclusivity, organizational pervasiveness is the most important. This is because pervasiveness affects occupational self-identity, the prime component of an occupational community. It is pervasiveness that facilitates the internalization of a value system that allows a person to identify with work colleagues. Organizational embrace and restrictive factors are related to the first two components of occupational communities through their effect on people's friendship and associational patterns, but this is only indirectly related (Salaman 1974: 36-37).

'[T]here are no known cases of occupational communities where members are not strongly involved in their work skills and tasks' (Salaman 1974: 37). However, while involvement is necessary, it alone is not sufficient enough a causal factor. At least two determinants are required, with the second determinant being either status-based or due to inclusivity.

The determinants are important because the situation that conditions the occupation will determine whether the occupational community can be identified as local or cosmopolitan (Salaman 1974: 38-41; following Gouldner 1957; Merton 1957; Reissman 1949). Cosmopolitan occupational communities are based on the occupation as a whole and are composed, potentially, of all members of the occupation. Members of this type are oriented toward the world outside and with respect to the role of their occupation as a whole, and they are likely to identify with any colleagues from that occupation. Thus, cosmopolitan communities are not geographically restricted. Local occupational communities, on the other hand, are composed of members who share a specific work situation, creating a geographic correlation. Furthermore, members of this type will not identify as strongly with others in the same occupation outside their own work situation. The type of occupational community, local or cosmopolitan, is related to the requisite second determinant that establishes the occupational community in conjunction with involvement (Salaman 1974: 41). In the case of local occupational communities, there are likely to be certain features of the work situation that prevents the member from establishing or maintaining relationships with non-work mates, for example restrictive factors or organizational embrace. For cosmopolitan communities, the second determinant is a feature of the occupation as a whole, for example pervasiveness or marginality, both of which limit the associational choices of members so that they have the most in common with peers within the occupation. 
This overview of the concept of occupational communities provides a theoretical understanding of the late Roman army and will be useful when considering the limitanei. A brief examination of the late Roman army indicates that its members can be identified as an occupational community. First, soldiers had an important notion of identity that encouraged separation from other types of identity. This came about through special legal status that allowed soldiers to publicly bear arms, allowed privileges regarding property control and inheritance, and they were tried separately in military courts (James 1999: 15). Soldierly identity did not stop with legal status, it was reproduced through military practices, whether it was membership in a contubernia, practicing drills, following dress regulations and styles, observing official holidays or religious rituals, and even through diet (King 1999). Such an identity construct enabled soldiers across the Empire to recognize and relate to each other, superseding (when need be) the divergent relationships cultivated by units long-garrisoned in one locality, as was typical in the later Empire. This was equally true for auxiliaries as it was for legionaries in the early Empire (Haynes 1999b), and would be the same for limitanei and comitatenses in the later Empire.

The soldiers and garrisons of the Roman armies were members of a military occupational community, but that community was not exclusive to soldiers or exclusively martial in character; it included non-combatant support staff and soldiers' dependants that provided a considerable part of the immediate labour and productive capacity of a military community (James 2001). Beyond that, soldiers were participants in other social structures, particularly in the later Empire. They may have been husbands, fathers, and/or brothers, owners of slaves, and patrons of clients, or clients themselves. Thus, the Roman frontier garrison was a community in the real sense of the word, as a population living together in proximity that was bound through social, economic, and ideological relationships. Each garrison in the frontier, however, participated in an empire-wide organization that allowed individual members from across the Empire to comprehend and relate to each other's circumstances in a sociologically meaningful way. It was this participation in the Roman army that provided a foundation of identity for the soldier and structured his social life.

\section{The 'End' of a Roman Frontier - A Theoretical Model}

The advantage of identifying the late Roman military as an occupational community is that it allows a theoretical link between the garrisons of the Empire and the state. It also provides a framework by which we can understand the collapse of Roman frontier garrisons. Starting with the premise that the late Roman military was a cosmopolitan occupational community that incorporated members from across the Empire, we can hypothetically chart the change. The late Roman imperial military ceased to exist when the Roman military ceased to be a cosmopolitan occupational community.

Initially, this loss of a trans-empire military identity was not disastrous. The various armies of the Empire still constituted occupational communities; however, they were now regionally based, 'local' types of occupational communities, specific to each frontier or regional field army. Even then, the imperial state could continue to exist, but the change from an empirewide to a regionally based identity indicates a fragmentation of the social solidarity that existed among soldiers through the Empire. The formalization in the Roman Empire between the limitanei and the comitatenses contributed to the eventual disparity between the state and its military. While the comitatenses provided a mobile military force, the limitanei were fixed to 
frontiers, reinforcing local social and economic connections between soldiers and their region of posting. Over time, regional differences in practice would further reinforce the notion of a regional occupational community. This fragmentation could continue, in principle, to the level of each fort/garrison, so that the occupational community truly was local.

Reduction of the scale of an occupational community does not necessarily affect the organization of military command structures or units. Community identity reinforces social solidarity and acts as 'social glue'. In military contexts, social cohesiveness amongst soldiers can facilitate the deployment and direction of units, or it can enable soldiers to challenge their commanders. As communities failed to relate to other military communities through the Empire, the effectiveness of command structures probably decreased.

Inclusivity can be identified as the critical factor in the maintenance of occupational identity, and a change in a member's sense of inclusiveness will affect a member's relationship to the occupational community as well as the scale of the community. The transformation of one cosmopolitan community to a number of local communities would be the result of decreasing levels of pervasiveness (which establishes norms), embrace (which controls the activities of members), and restrictive factors (which affects non-work activities).

These changes in the levels of inclusivity would be consistent with the fragmentation of imperial power in the later Western Empire. A key group for the understanding of inclusivity of frontier garrisons would be the officer corps of the limitanei. To what extent were they locally raised, recruited, and trained? How often, if at all, were they transferred between different garrisons? How socially mobile were they? These questions are important because it is the officer corps that represents the interests of the state on the ground and keeps the frontier in line with imperial interests. Unfortunately, our knowledge of this group of officers, compared to those of the comitatenses, is slight and answering these questions is difficult. However, the officer corps can be examined archaeologically through investigation of material culture and the use of space. For example, praetoria or other officers' quarters and the use and distribution of high status goods can provide information that can be contrasted to the 'average' soldier.

The concept of an occupational community is archaeologically visible, particularly if the focus is not on individual identity, but on the 'identity' of the community. Thus, we can compare the internal layout of forts through the Empire, and the form of the buildings themselves. Any changes that deviate from 'standard' military architecture of the time suggest a rejection of regularized, institutional military practices imposed from above. When there are changes, what are the reasons for these changes? Social reasons must be considered as fully as tactical and economically functional reasons. If we consider Hadrian's Wall in its latest archaeological phases, there are a number of changes away from the regularly organized forts of earlier centuries. For example, road pavements are rougher; horrea are demolished; new praetoria are built in forts, or at the very least renovated; chalet-style barracks are the norm; and new buildings make greater use of timber as the primary building material rather than stone.

Artefactual studies can also contribute to a community profile; for example, the fourth century predominance of Crambeck tablewares and Huntcliff type coarse wares (Evans 2000), typological changes in artefact assemblages (Cool 2000), and dietary shifts (King 1999). These examples suggest a number of changes occurring in the late garrisons along the Wall. Further changes can be seen in the sub-Roman period, like the gate sequence at South Shields (Bidwell and Speak 1994), the 'church' built into/over the praetoria at Vindolanda (Birley 1999), the hall sequence at Birdoswald (Wilmott 1997), and the timber structures discovered at Stanwix 
and Carlisle (McCarthy 2002: 135-136). These changes suggest a distinct regional frontier community by the late fourth century, possibly fragmenting into more localized communities in the sub-Roman period.

In conclusion, the archaeological evidence for the 'end' of Hadrian's Wall needs to be considered in its greater context. The significance of the military garrison and the organization of frontier economy and society cannot be ignored. It is this context of a military community in a frontier, socially, economically, and ideologically tied to the state while at the same time integrated with the frontier region that must form the basis through which we examine the material evidence. Changes observable in the material evidence allow for empirical study of the collapse and transformation of Roman frontiers, by which we can test our theoretical understanding of the collapse of complex societies and frontier dynamics.

Department of Archaeology, University of York

\section{Acknowledgements}

This paper is derived from doctoral research conducted at the University of York. I would like to thank my advisor Steve Roskams, and my colleague Martin Pitts for reading and commenting on earlier drafts of this paper. I would also like to thank Helen Goodchild for organizing the session at TRAC in which this paper was presented and the TRAC editorial committee for suggested improvements to the paper. Any mistakes remain my own.

\section{Bibliography}

Alston, R. 1995. Soldier and Society in Roman Egypt: A Social History. London: Routledge.

Bidwell, P. 1985. The Roman Fort of Vindolanda at Chesterholm, Northumberland. London: Historic Buildings and Monuments Commission for England.

Bidwell, P. and Speak, S. 1994. Excavations at South Shields Roman Fort, vol. 1. Newcastle: Society of Antiquaries.

Birley, R. 1999. Vindolanda. In P. Bidwell (ed.) Hadrian's Wall 1989-1999. Carlisle: Cumberland and Westmoreland Antiquarian and Archaeological Society and the Society of Antiquaries of Newcastle upon Tyne: 130-136.

Breeze, D. and Dobson, B. 1978. Hadrian's Wall. Second edition. London: Penguin.

Breeze, D. and Dobson, B. 2000. Hadrian's Wall. Fourth edition. London: Penguin.

Bury, J.B. 1920. The Notitia Dignitatum. Journal of Roman Studies 10: 131-154.

Casey, P.J. 1993. The end of garrisons on Hadrian's Wall: an historico-environmental model. In D. Clark, M. Roxan and J. Wilkes (eds.) The Later Roman Empire Today. London: Institute of Archaeology: 69-80.

Collingwood, R.G. and Myres, J.L.N. 1937. Roman Britain and the English Settlements. Oxford: Clarendon Press.

Cool, H.E.M. 2000. The parts left over: material culture into the fifth century. In T. Wilmott and P. Wilson (eds.) The Late Roman Transition in the North. B.A.R. 299. Oxford: Archaeopress: 47-79.

Craster, H.H.E. 1914. The Last Days of the Roman Wall. Archaeological Journal 71: 25-44.

Dark, K. 1992. A Sub-Roman Re-defence of Hadrian's Wall? Britannia 23: 111-120.

Dark, K. and Dark, P. 1996. New Archaeological and Palynological Evidence for a Sub-Roman Reoccupation of Hadrian's Wall. Archaeologia Aeliana. Fifth series. 24: 57-72.

Etzioni, A. 1961. A Comparative Analysis of Complex Organisations. New York: Free Press. 
Evans, J. 2000. The End of Roman Pottery in the North. In T. Wilmott and P. Wilson (eds.) The Late Roman Transition in the North. B.A.R. 299. Oxford: Archaeopress: 39-46.

Febvre, L. 1922. La terre et l'evolution humaine. Paris: Michel (reprinted 1970).

Gerstl, J.E. 1961. Determinants of Occupational Community in High Status Occupations. Sociology Quarterly 2: 37-48.

Gillam, J.P. 1949. Also, Along the Line of the Wall. Transactions of the Cumberland and Westmorland Antiquarian and Archaeological Society. Second series. 49: 38-58.

Goetz, H. 2001. Concepts of Realm and Frontiers from Late Antiquity to the Early Middle Ages: Some Preliminary Remarks. In W. Pohl, I. Wood, and H. Reimitz (eds.) The Transformation of Frontiers, From Late Antiquity to the Carolingians, Transformation of the Roman World 10. Boston: Brill: 7382.

Goffman, E. 1969. Role Distance. In E. Goffman (ed.) Where the Action Is. London: Allen Lane: 37-103.

Goldsworthy, A. and Haynes, I. (eds.) 1999. The Roman Army as a Community. Portsmouth: Journal of Roman Archaeology.

Gouldner, A.W. 1957. Cosmopolitans and Locals: Towards and Analysis of Latent Social Roles. Administrative Science Quarterly 2: 281-306.

Haynes, I. 1999a. Introduction: the Roman army as a community. In A. Goldsworthy and I. Haynes (eds.) The Roman Army as a Community. Portsmouth: Journal of Roman Archaeology: 7-14.

Haynes, I. 1999b. Military service and cultural identity in the auxilia. In A. Goldsworthy and I. Haynes (eds.) The Roman Army as a Community. Portsmouth: Journal of Roman Archaeology: 165-174.

Isaac, B. 1990. The Limits of Empire: The Roman Army in the East. Oxford: Clarendon Press.

James, S. 1984. Britain and the Late Roman Army. In T. Blagg and A. King (eds.) Military and Civilian in Roman Britain. B.A.R. 136. Oxford: British Archaeological Reports: 161-186.

James, S. 1999. The Community of Soldiers: a major identity and centre of power in the Roman empire. In P. Baker, C. Forcey, S. Jundy and R. Witcher (eds.). TRAC 98: Proceedings of the Eighth Annual Theoretical Roman Archaeology Conference, Leicester 1998, Oxford: Oxbow: 14-25.

James, S. 2001. Soldiers and civilians: identity and interaction in Roman Britain. In S. James and M. Millett (eds.) Britons and Romans: advancing an archaeological agenda. York: Council for British Archaeology: 77-89.

Janowitz, M. 1960. The Professional Soldier. Glencoe, IL: Free Press.

Jones, M. E. 1996. Geographical-Psychological Frontiers in Sub-Roman Britain. In R. Mathisen and H. Sivan (eds.) Shifting Frontiers in Late Antiquity. Aldershot: Variorum: 45-58.

King, A. 1999. Animals and the Roman Army: the evidence of animal bones. In A. Goldsworthy and I. Haynes (eds.) The Roman Army as a Community. Portsmouth: Journal of Roman Archaeology: 139149.

Kopytoff, I. 1993. The Roman Frontier and the Uses of Comparison. In P. Brun, S. van der Leeuw, and C.R. Whittaker (eds.). Frontières d'empire: Nature et signification des frontières romaines. actes de la Table ronde internationale de Nemours, 21-22-23 mai 1992. Ile-de-France: Mémoires du Musée de Préhistoire: 143-147.

Lapradelle, A.G. de. 1928. La Frontiére; Etude du Droit International. Paris: Les Editions Internationales.

Lattimore, O. 1940. Inner Asian frontiers of China. New York: American Geographical Society.

Lightfoot, K. and Martinez, A. 1995. Frontiers and Boundaries in Archaeological Perspective. Annual Review of Anthropology 24: 471-92.

Mann, J.C. 1979. Hadrian's Wall: The Last Phases. In P. Casey (ed.) The End of Roman Britain. B.A.R. 71. Oxford: Tempus Reparatum: 144-151.

McCarthy, M. 2002. Roman Carlisle and the Lands of the Solway. Stroud: Tempus.

Merton, R.K. 1957. Social Theory and Social Structures. New York: Free Press.

Paynter, R. 1985. Surplus Flow between Frontiers and Homelands. In S. Green and S. Perlman (eds.) The Archaeology of Frontiers and Boundaries. Orlando: Academic Press: 163-211. 
Pegler, A. 2000. Social Organization within the Roman Army. In G. Fincham, G. Harrison, R. Holland and L. Revell (eds.) TRAC 99: Proceedings of the Ninth Annual Theoretical Roman Archaeology Conference, Durham 1999. Oxford: Oxbow: 37-43.

Pohl, W., Wood, I., and Reimitz, H. 2001. The Transformation of Frontiers, From Late Antiquity to the Carolingians. Transformation of the Roman World 10. Boston: Brill.

Pollard, N. 1996. The Roman army as 'total institution' in the Near East? Dura-Europos as a case study. In D.L. Kennedy (ed.) The Roman Army in the East. Portsmouth: Journal of Roman Archaeology: 217-227.

Reissman, L. 1949. A Study in Role Conceptions in Bureaucracy. Social Forces 27: 306-331.

Salaman, G. 1974. Community and Occupation: An exploration of work/leisure relationships. Cambridge: Cambridge University Press.

Trousset, P. 1980. Signification d'une frontière: Nomades et sedentaires dans la zone du limes d'Afrique. In W. Hanson and L. Keppie (eds.) Roman Frontier Studies XII, 1979. B.A.R. International Series 71. Oxford: Tempus Reparatum: 931-942.

Turner, F. J. 1893. The Significance of the Frontier in American History. Annual Report of the American Historical Association for the year 1893: 199-207.

Whittaker, C. 1994. Frontiers of the Roman Empire: A Social and Economic Study. London: Johns Hopkins University Press.

Wilmott, T. 1997. Birdoswald, Excavations of a Roman fort on Hadrian's Wall and its successor settlements: 1987-92. London: English Heritage.

Wilmott, T. 2000. The late Roman transition at Birdoswald and on Hadrian's Wall. In T. Wilmott and P. Wilson (eds.) The Late Roman Transition in the North. B.A.R. 299. Oxford: Archaeopress: 13-23.

Wilmott, T. and Wilson, P. (eds.) 2000. The Late Roman Transition in the North. B.A.R. 299. Oxford: Archaeopress. 